\title{
PHAEODACTYLUM TRICORNUTUM MICROALGAE GROWTH RATE IN HETEROTROPHIC AND MIXOTROPHIC CONDITIONS
}

\begin{abstract}
K. C. C. Morais ${ }^{\text {a }}$,
R. L. L. Ribeiro ${ }^{a}$,

K. R. Santos ${ }^{a}$,

D. M. Taher ${ }^{a}$,

A. B. Mariano ${ }^{a}$, and J. V. C. Vargas ${ }^{b}$

${ }^{a}$ Universidade Federal do Paraná

Núcleo de Pesquisa e Desenvolvimento em

Energia Auto-Sustentável, Jardim das

Américas, CP. 19011, Curitiba, Paraná, Brasil

biokeli2000@gmail.com

robertlarabr@yahoo.com.br

kassi.ribeiro@hotmail.com

dhyogomt@gmail.com

andrebmariano@gmail.com

${ }^{\mathrm{b}}$ Universidade Federal do Paraná

Departamento de Engenharia Mecânica

Bairro Jardim das Américas

CP. 19011, Curitiba, Paraná, Brasil

jvargas@demec.ufpr.br

ABSTRACT

The Brazilian National Program for Biofuel Production has been encouraging diversification of feedstock for biofuel production. One of the most promising alternatives is the use of microalgae biomass for biofuel production. The cultivation of microalgae is conducted in aquatic systems, therefore microalgae oil production does not compete with agricultural land. Microalgae have greater photosynthetic efficiency than higher plants and are efficient fixing $\mathrm{CO}_{2}$. The challenge is to reduce production costs, which can be minimized by increasing productivity and oil biomass. Aiming to increase the production of microalgae biomass, mixotrophic cultivation, with the addition of glycerol has been shown to be very promising. During the production of biodiesel from microalgae there is availability of glycerol as a side product of the transesterification reaction, which could be used as organic carbon source for microalgae mixotrophic growth, resulting in increased biomass productivity. In this paper, to study the effect of glycerol in experimental conditions, the batch culture of the diatom Phaeodactylum tricornutum was performed in a 2-liter flask in a temperature and light intensity controlled room. During 16 days of cultivation, the number of cells per ml was counted periodically in a Neubauer chamber. The calculation of dry biomass in the control experiment (without glycerol) was performed every two days by vacuum filtration. In the dry biomass mixotrophic experiment with glycerol concentration of $1.5 \mathrm{M}$, the number of cells was assessed similarly in the 10th and 14th days of cultivation. Through a volume element methodology, a mathematical model was written to calculate the microalgae growth rate. Was used an equation that describes the influence of irradiation and concentration of nutrients in the growth of microalgae. A simulation time of 16 days was used in the computations, with initial concentration of $0.1 \mathrm{~g} \mathrm{l}^{-1}$. In order to compare simulation data with experimental data, we calculated the dry weight in 8 points in the course of sixteen days. In this way, it was possible to assess graphically biomass concentration versus time through the experiments and by numerical simulation. It was identified that the simulation results were consistent with the experiments and that the addition of glycerol greatly influenced the growth of microalgae. In the present analysis, the glycerol added increased $30 \%$ in biomass.
\end{abstract}

Keywords: Matematical modeling, Mixotrophic, Glycerol, Biomass.

\section{NOMENCLATURE}

$\mu \quad$ Specific growth rate $\left(h^{-1}\right)$

$\mathrm{N} \quad$ Nutrient levels,

$\mu_{\max } \quad$ Maximum specific growth rate $\left(h^{-1}\right)$

$\mathrm{K}_{\mathrm{N}} \quad$ saturation constant for the relationship between nutrient levels and maximal specific growth rate

$D$ Dilution rate $\left(\boldsymbol{h}^{-\mathbf{k}}\right)$

Frax Maximum specific growth rate $\left(\boldsymbol{h}^{-1}\right)$

$\nabla_{0, n a x}$ Maximum incident light intensity on culture surface $\left(a \overline{5} m^{-2} s^{-1}\right)$

$C_{0}$ Initial Biomass concentration $\left(\mathrm{gl}^{-1}\right)$

$a, b \quad$ Parameters to be defined

$T^{\prime} \quad$ Absolute temperature $(\mathrm{K})$

$T_{0} \quad$ Initial temperature $(K)$

\section{INTRODUCTION}

Microalgae are unicellular photosynthetic organisms that require relatively simple nutrients and whose biomass can be used to obtain biocomposites, food supplement for humans and animals and as a source of biofuels (Andrade and Costa, 2008), its homogeneous biomass allows greater recovery than oilseeds in which only parts of the plant are directed to the process of interest. Due to large commercial applications that employ microalgae, in particular for the production of biodiesel is necessary to perform cultures with high density. For this, the microalgae grown in photobioreactors compacts are studied by the Center for Energy Research and Development in Self-Sustained (NPDEAS) with a focus on biodiesel production. The microalgae Phaeodactylum tricornutum (Bohlin, 1897) has been studied by our 
research group due to its characteristics for the production of biofuels.

Microalgae cultures can be autotrophic, where the cell through the photosynthesis process performs its vital functions, heterotrophic cultures, where cells have available all the nutrients needed to perform their metabolic processes without the presence of light and mixotrophic cultures, in which the autotrophic and heterotrophic metabolism operate, the microalgae simultaneously assimilates $\mathrm{CO}_{2}$ autotrophic and organic carbon supplied to it. According to the literature, some species of microalgae show much higher yield when grown under Mixotrophic regime. The Mixotrophic regime is broadly defined as a system of growth in which organic carbon and $\mathrm{CO}_{2}$ are simultaneously treated by both photosynthetic and respiratory metabolism. The specific rate of growth of the mixotrophic culture is therefore approximately the sum of specific growth rate of cells grown in photoautotrophic and heterotrophic conditions. (Richmond, 2004). In dense cultures, the assimilation of inorganic carbon is impaired due to high density cell, due to the low availability of light. When microalgae assimilate more carbon has its production of carbohydrates, proteins and lipids increased (Derner, 2006). Cerón García et al. (2006), performing mixotrophic cultivation with microalgae Phaeodactylum tricornutum grown with glycerol and $\mathrm{CO}_{2}$ injection, reached biomass of $7.04 \mathrm{~g} / \mathrm{L}$, while cultivation without addition of glycerol did not reach $1 \mathrm{~g} / \mathrm{L}$. The additional carbon source for these cultures enables higher yield of biomass, because there is greater availability of carbon than the produced via photosynthetic metabolism. The carbon source is a major component in the production of microalgal biomass (Radmann et al., 2009). Glycerol is an interesting carbon source in mixotrophic cultures where the focus is the production of biodiesel due to its availability resulting from the transesterification process. Mixotrophic cultures with various carbon sources have been studied (Cerón Garcia et al., 2006; \& Costa Andrade, 2008; Radmann, 2009).

Mathematical modeling has helped to estimate the rate of cell growth, based on parameters that can influence productivity, such as temperature, light intensity and nutrient concentration. The model relates the response variable to the explanatory variables and also how much the expected response deviates from the response observed (Lacerda, 2009). García-Malea (2005), analyzed by mathematical modeling the behavior of cultures Haematocaccus pluvialis under the influence of light intensity and concentration of nutrients in order to allow greater production yields. Ribeiro (2009) modeled temperature and light intensity to identify the phenomenon of photoinhibition, which causes the decrease or even cell death, within tube photobioreactors. Currently the high cost of production in the cultivation of microalgae in photobioreactors has been a barrier. However, the modeling to predict optimal conditions for cultivation can promote increased productivity of crops and hence reduce the production cost of biomass.

\section{EXPERIMENT FOR DETERMINATION OF DRY BIOMASS}

Experiments with the microalga Phaeodactylum tricornutum, was sold by the Group Integrated Aquaculture UFPR for the Center for Energy Research and Development in Self-Sustained (NPDEAS). The culture was performed in erlenmeyers with a capacity of 2 liters, maintained in a room in an environment of temperature between 18-21 ${ }^{\circ} \mathrm{C}$ under constant aeration with atmospheric air flow of $2.7 \mathrm{~L} / \mathrm{min}$ in each erlenmeyers. The luminous intensity of 5500 lux was maintained by fluorescent lamps of $40 \mathrm{~W}$ at full photoperiod. The culture medium F/2 modified Guillard was prepared in sea water standard at $15 \%$ and subsequently autoclaved. After reaching room temperature, glycerol was added.

The initial inoculum for experiments was standardized to $30.10^{4}$ cells $/ \mathrm{mL}$ according to Soares (2010), resulting in about $100 \mathrm{mg} / \mathrm{L}$ of biomass, resembling thus the work of García Cerón et al. (2000) where the concentration of biomass used for inoculation between 70-100 mg/L. The experiments were performed in duplicate resulting in four treatments, two control experiments (without glycerol) and two with the addition of glycerol at a concentration of 0,15 M. The cultures were monitored daily by withdrawing a $1 \mathrm{ml}$ aliquot for cell counting in a Neubauer chamber for observation of cell growth.

The dry biomass was determined every two days during 16 days. Due to the amount of medium removed and grown during the days, it was not possible to determine daily dry biomass. Due to the large amount of sample used for that could be made in triplicate, the initial amount of cultivation becomes insufficient, so it was determined in 8 days during the 16 days of cultivation. To determine the biomass was collected $150 \mathrm{~mL}$ of medium for the biomass could be quantified. For this, we filtered $50 \mathrm{ml}$ of culture medium quantitative filter paper with the aid of the vacuum pump. The paper filters were incubated at $60^{\circ} \mathrm{C}$ until the weight remained constant. The dry biomass was estimated by the difference of the mass of paper before and after filtration.

The intention of this paper is to propose data of dry biomass in $\mathrm{g} / \mathrm{L}$ in order to compare them with results of numerical simulation provides a validation of the mathematical model.

\section{MATHEMATICAL MODELLING OF THE VELOCITY OF CELL GROWTH WITH} ADDITION OF GLYCEROL 
Through computer modeling using volume elements we built a model to calculate the rate of growth for the microalgae $P$. tricornutum using parameters of a cylinder 2-liter volume. Equation (1) proposed by Molina et al. (2005) was used, it demonstrates the influence of irradiation and concentration of nutrients in the growth of microalgae

$$
\mu=\frac{\left(\frac{N \mu N_{\max }}{K_{N}+N}\right) I_{a v}^{n}}{(a-b N)^{n}+I_{a v}^{n}}
$$

To calculate the growth rate $(\mu)$, we used $K_{N}$ which is the saturation constant for the relationship between nutrient levels $(\mathrm{N})$ and $\mu_{\max }$ observed. The growth rate independent of specific nutrients is given by $\mu \mathrm{N}_{\max }$. Figure 1 shows the experiments carried out experimentally and through simulation, both illuminated by lamps of $40 \mathrm{~W}$ and total volume of 1,7l of culture medium. Figure 1a represents the mixotrophic cultivation, in which glycerol was added, both in the flask used in the experimental plot as the cylinder used in the simulation and Figure 1b, autotrophic cultivation, without the presence of glycerol, also for the two geometries investigated in this work. It is worth remembering that the geometry of the system was not considered because, experimentally the culture was grown in 2 liter erlenmeyer. The erlenmeyer has a geometry that does not guarantee the cultivation excellent distribution of air, light and other factors that influence their growth. The lower region by having a larger radius, then leads to a more intense self-shading due to high concentration of biomass in relation to the upper region of the bottle. Due to the difficulty of adapting the geometry of the conical in mathematical modeling, these dimensions were adjusted resulting in a cylinder $10 \mathrm{~cm}$ in diameter x $26,5 \mathrm{~cm}$ high. Therefore, in the experiment the erlenmeyer was used, and a cylinder model was used, this difference in geometry can be seen in Figure 1. This figure can also be seen that the variables are of paramount importance to the growth of biomass: light intensity provided by lamps of $40 \mathrm{~W}$, and the aeration system that provides the agitation of the culture medium while minimizing the effects of self-shading and allowing all cells to suffer exposure to light.

The computer model uses data related to the microalgae Phaeodactylum tricornutum acquired literature Pérez et al. (2008), Grima et al. (2001), Fernández et al. (1997) and Sánchez et al. (2008) and parameters of cylindrical photo bioreactor (erlenmeyer conical). Table 1 summarizes the constants used in numerical simulation.

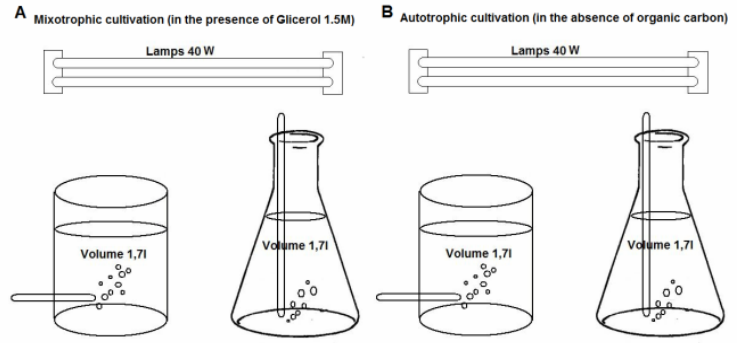

Figure 1. Sketch of the performed experiments in the laboratory.

Table 1. Constants used in numerical simulation

\begin{tabular}{|c|}
\hline Volume $=2 \mathrm{l}$ \\
\hline$C_{0}=0.100 \mathrm{~g} / \mathrm{l}$ \\
\hline Duration $=384$ horas $(1$ dias $)$ \\
\hline Glycerol $=0,15 \mathrm{M}$ \\
\hline$T_{0}=293 \mathrm{~K}$ \\
\hline$I_{0, \text { Max }}=2500 \mu \mathrm{Em}^{-2} \mathrm{~s}^{-1}$ \\
\hline Radius $=5 \mathrm{~cm}^{-}$ \\
\hline Air flow $=2,7 \mathrm{~L} / \mathrm{min}$ \\
\hline
\end{tabular}

\section{RESULTS AND DISCUSSIONS}

\section{PRODUCTION OF DRY BIOMASS P. tricornutum}

The concentration of dry biomass of diatom $P$. tricornutum determined every two days during cultivation with glycerol added at the beginning of cultivation was higher than the control experiment. The experiment conducted in the presence and absence of glycerol can be seen in Figure 2a and Figure 2b, respectively. Due to the higher concentration of cells found in the experiment with glycerol, this presents a darker color that can be clearly observed.

Table 2 presents the results of dry biomass in grams per liter $(\mathrm{g} / \mathrm{L})$. Column 1 and 2 are the simulation data while columns 3 and 4 refer to experimental data. The two simulations consider the cultivation regime mixotrophic (with addition of additional carbon source), one of which occurs in light/12h $12 \mathrm{~h}$ dark (1), and the other in 24 hours of light (2). The results presented in column 3 relating to the cultivation was performed in laboratory scale under mixotrophic light intensity under constant during 24 hours (3), while an experiment conducted under autotrophic (2) under the same light conditions, was evaluated.

The maximum concentration of biomass obtained from cultivation mixotrophic was 1,294 g/L while that in the autotrophic cultivation maximum biomass obtained was 0,88 g/L. Growing mixotrophic with the addition of glycerol was $31,6 \%$ higher than the autotrophic culture. The biomass obtained in the simulation with the same conditions as the experiment was $1.3 \mathrm{~g} / \mathrm{L}$, this result was the same as obtained experimentally. Figure 3 shows the results 
of the simulation with 24 hours of light and the experimental data performed under constant light for 24 hours, both with initial concentration of $0,1 \mathrm{~g} / \mathrm{L}$ until the maximum yield of about $1.3 \mathrm{~g} / \mathrm{L}$ in the course of 16 days of cultivation. Below these curves are presented the curves of the experiment mixotrophic and autotrophic.

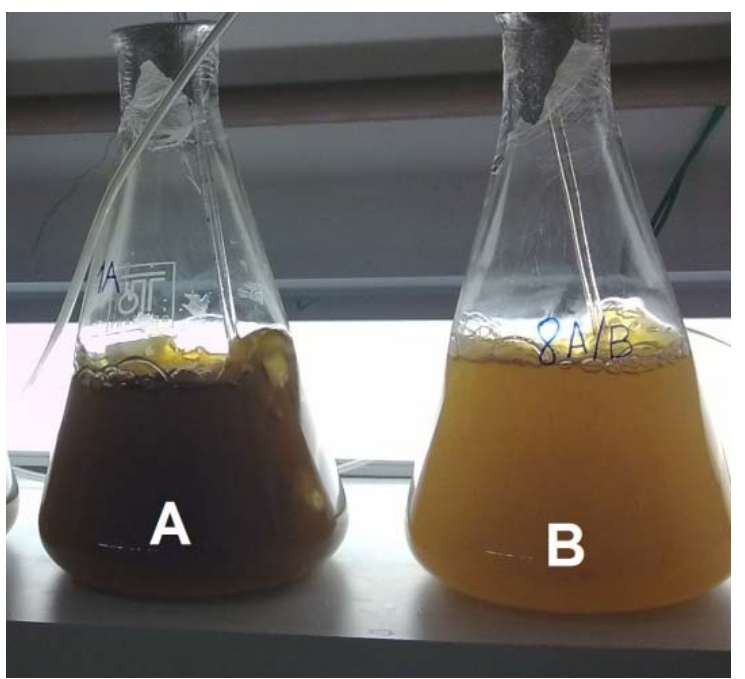

Figure 2. A) larger algae concentration medium with glycerol; B) smaller algae concentration medium without glycerol.

Tabela 2. Biomass concentration during 16 days of each experiment.

\begin{tabular}{|c|c|c|c|c|}
\hline $\begin{array}{c}\text { Time } \\
(h)\end{array}$ & $\begin{array}{c}\mathbf{1} \\
(12 \mathrm{~h} \text { light }) \\
\text { mixotrophic }\end{array}$ & $\begin{array}{c}\mathbf{2} \\
(24 \mathrm{~h} \text { light }) \\
\text { mixotrophic }\end{array}$ & $\begin{array}{c}\mathbf{3} \\
(24 \mathrm{~h} \text { light }) \\
\text { mixotrophic }\end{array}$ & $\begin{array}{c}\mathbf{4} \\
(24 \mathrm{~h} \text { light }) \\
\text { autotrophic }\end{array}$ \\
\hline 0 & 0.100 & 0.100 & 0.100 & 0.100 \\
\hline 24 & 0.131 & 0.199 & - & - \\
\hline 48 & 0.172 & 0.324 & 0.201 & 0,114 \\
\hline 72 & 0.221 & 0.451 & - & - \\
\hline 96 & 0.280 & 0.567 & 0.272 & 0.204 \\
\hline 120 & 0.349 & 0.671 & - & - \\
\hline 144 & 0.425 & 0.761 & 0.386 & 0.274 \\
\hline 168 & 0.508 & 0.841 & - & - \\
\hline 192 & 0.596 & 0.911 & 0.511 & 0.387 \\
\hline 216 & 0.685 & 0.975 & - & - \\
\hline 240 & 0.781 & 1.031 & 0.804 & 0.593 \\
\hline 264 & 0.872 & 1.080 & - & - \\
\hline 288 & 0.961 & 1.125 & 0.848 & 0.636 \\
\hline 312 & 1.048 & 1.167 & - & - \\
\hline 336 & 1.133 & 1.208 & 1.013 & 0.746 \\
\hline 360 & 1.216 & 1.243 & - & - \\
\hline 384 & 1.296 & 1.271 & 1.294 & 0.885 \\
\hline
\end{tabular}

By comparing the experimental data with the simulation in Figure 3, should be considered that the modeling provides optimum conditions, while the experiment undergoes over time limitations that affect their growth. $\mathrm{pH}$ change, a decrease of nutrients in the environment, self-shading due to the increase in biomass concentration, instability of temperature on extremely hot days or cold and even variation in light intensity due to the geometry of the crop although the light intensity incident be constant, are some of the variables that can influence the culture. Therefore, it is justified the fact that the growth rate obtained from simulation is slightly higher throughout the hours.

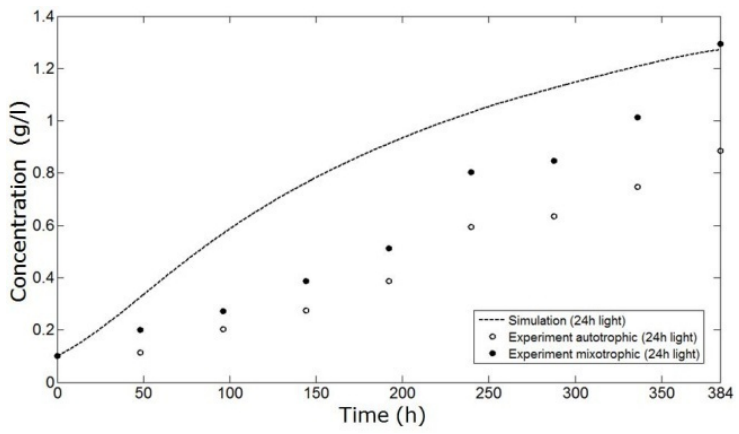

Figure 3. Biomass concentration over time to simulate 24 hours of light.

By comparing the experimental results with the results of numerical simulation in Figure 4, it was found that cultivation mixotrophic conducted with a photoperiod of $12 \mathrm{~h}$ light and $12 \mathrm{~h}$ dark was closer to the result obtained experimentally, which was grown under light for 24 hours. The dashed line in Figure 4 refers to data obtained from numerical simulations conducted with a photoperiod of $12 \mathrm{~h}$. It is noticed in common with the experimental data, we can say that photoperiod but increased in the simulation was proportional to the deleterious effects that limited the growth in cultivation conducted with a photoperiod of $24 \mathrm{~h}$.

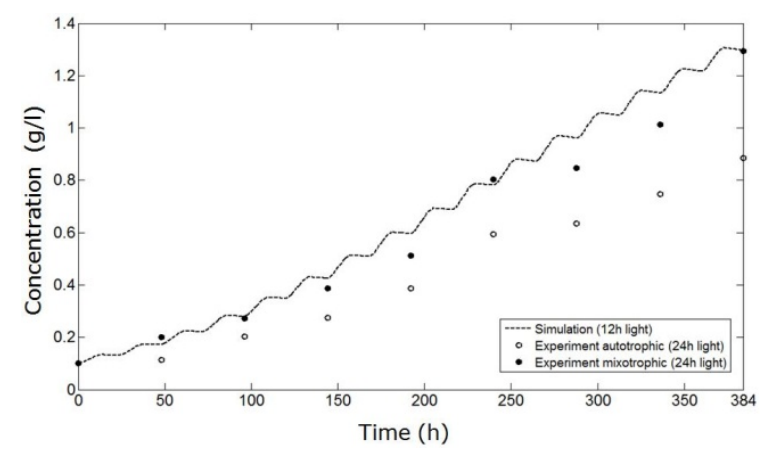

Figure 4. Biomass concentration over time to simulate 12 hours of light.

\section{CONCLUSION}

The cultures mixotrophic can increase the concentration of microalgae biomass as the carbon source is added in appropriate concentrations demonstrating the metabolic capacity of some species of microalgae. The mathematical model was able to estimate the biomass concentration with glycerol, approaching many of the experimental results. It is important to use numerical simulation to be checked the extreme influence of variables on the productivity of microalgae, thus establishing appropriate conditions so that you can achieve maximum productivity in cultures performed. Simulations with full and partial photoperiod were 
acceptable when compared with the experiment conducted at a laboratory scale, provided that the variables during cultivation. As the mathematical model proposed ideal conditions and actual experimental conditions, the results were enough to validate the proposed model.

\section{ACKNOWLEDGMENT}

The authors from NPDEAS acknowledge CNPq, CAPES and Nilko Metalurgia Ltda. for funding the research and GIA and UFPR for technical support for the infrastructure

\section{REFERENCES}

Ancién Fernández, F. G., Garcia Camacho, F., Sánchez Pérez, J. A., Fernández Sevilha, J. and Grima, E. M., 1998, A model for light distribution and average solar irradiance inside outdoor tubular photobioreactors for microalgal mass culture. Effects of dilution rate, tube diameter and solar irradiance, Biotechnol. Bioeng., Vol. 35, No. 58, pp. 605-611.

Andrade, M. R., and Costa, J. A., 2008, Cultivo da microalga Spirulina platensis em fontes alternativas de nutrientes. Ciência Agrotec., Vol. 32, No. 5, pp. 1551-1556. (in Portuguese)

Baker, N. R., and Bower,J. R., 1994, Photoinhibition of Photosynthesis: from molecular mechanisms to the field. Ed. Bios Scientific Publishers.

Cerón Garcia, M. C., Camacho, F. G., Mirón, A. S., Sevilla, J. M. F., Chisti, Y., and Grima, E. M., 2006, Mixotrophic production of marine microalgae Phaeodactylum tricornutum on various carbon sources, J. Microbiol. Biotechnol, Vol. 16, No. 5, pp. 689-694.

Cerón Garcia, M. C., Camacho, F. G., Fernández Sevilla, J. M., Acién Fernández, F. G. , and Grima E. M., 2000, Mixotrophic growth of Phaeodactylum tricornutum on glycerol: growth rate and fatty acid profile, J. of Applied Phycology, Vol. 12, No. 1, pp. 239-248.

Cerón Garcia, M. C., Mirón A. S.; Sevilla, J. M. F., Grima E. M., and Camacho F. G., 2005, Mixotrophic growth of the microalgae Phaeodactylum tricornutum. Influence of different nitrogen and organic carbon sources on productivity and biomass composition, J. Process Biochemistry, Vol. 40, No. 1, pp. 297-305.

Chen, G. Q., Jiang, Y, and Chen, F., 2008, Variation of lipid class composition in Nitzschia laevis as a response to growth temperature change, Food Chemistry, Vol. 100, No. 1, pp. 88-94.

Evers, E. G., 1991, A Model for Light-Limited Continuous Cultures: Growth, Shading, and Maintenance. Biotechnology and Bioengineering, Vol. 38, No. 3, pp. 254-259.

Fernández, F. G. A., Pérez, J. A. P., Sevilla, J. M. F.,Camacho, F. G., and Grima, E. M., 1997, Model for Light Distribution and Average Solar Irradiance Inside Outdoor Tubular Photobioreactors for the Microalgal Mass Culture, Biotechnology and Bioengineering, Vol. 55, No. 5, pp. 605-611.

García Sanchéz, J. L., Molina Grima, E., García Camacho, F., Sánches Pérez, J. A., and López Alonso, D., 1994, Estudio de macronutrientes para La producción de PUFAs a partir de La microalga marina Isochysis galbana, Grasas Aceites Sevilla, Vol. 45, No. 5, pp. 323-332. (in Spanish)

Goldman, J. C. and Ryther, J. H., 1976, Temperature-influenced species competition in mass cultures of marine phytoplankton, Biotechnology and Bioengineering, Vol. 18, No. 8, pp. 1125-1144.

Grima, E. M., Camacho, F. G., Pérez, J. A .S., Sevilla, J. M. F., Fernandez, F. G., and Contreras Gomez, A, 1994, A mathematical model of microalgal growth in light-limited chemostat culture. J. Chem. Tech. Biotechnol., Vol. 61, No. 2, pp. 167173.

Lourenço, S. O., 2006. Cultivo de microalgas marinhas - princípios e aplicações. Ed. Rima. São Carlo, Brazil. (in Portuguese)

Mariano, A. B., Torrens, J., and Satyanarayana, K. G., 2009, Energia auto-sustentável a partir de biodiesel derivado de microalgas, in: $4^{\circ}$ Congresso Internacional de Bioenergia, 2009, Curitiba. $4^{\circ}$ Congresso Internacional de Bioenergia; $1^{\circ}$ Congresso Brasileiro de Geração Distribuída e Energias Renováveis, Expounimed, Curitiba, Brazil. p. 62. (in Portuguese)

Molina Grima, E., Fernandez, F. G. A. and Chisti, Y, 2001, Tubular photobioreactor design for algal cultures. Journal of Biotechnology, Vol. 92, No. 2, pp. 113-131.

Molina Grima, E., Pérez, J. A. S., García Camacho, F., Fernández Sevilla, J. M. and Acién Fernández, F. G., 1996, Productivity analysis of outdoor chemostat culture in tubular air-lift photobioreactors, Journal of Applied Phycology, Vol. 8, No. 4-5, pp. 369-380.

Molina Grima, E., Malea-García, M. C., Brindley, C., Del Rio, E., Acién, F. G., and Fernández, J. M., 2005, Modelling of growth and acumulation of carotenoids in Haematococcus pluvialis as a function of irradiance and nutrients supply, Biochemical Engeneering, Vol. 26, No. 2-3, pp. 107-114.

Penteado, D. M. R., 2010, Estudos de otimização do meio de cultura para a microalga Phaeodactylum tricornutum para produção de lipídios, Master Thesis, Universidade Federal do Paraná, Curitiba, Brazil. (in Portuguese)

Pérez, B. E., Pina, C. I. and Rodriguez, L. P., 2008, Kinetic model for growth of Phaeodactylum tricornutum in intensive culture photobioreactor, Biochemical Engineering Journal, Vol. 40, No. 3, pp. 520-525. 
Pérez, H. E. B., 2007, Biodiesel de Microalgas Parte 1. Energia Verde - Biodiesel, MDL e Tecnologia em Microalgas. (in Portuguese)

Radmann, E., Oliveira, C. F., Zanfonato, K., and Vieira, J. A., 2009, Cultivo Mixotrófico da Microalga Spirulina $s p$. LEB-18 com Adição Noturna de Diferentes Fontes de Carbono Orgânico, in: XVII Simpósio Nacional de Bioprocessos, Natal-RN, p. 123. (in Portuguese)

Richmond, A., 1992, Mass culture of cyanobacterium. In Man, N. H. \& Carr, N. G. (eds) Photosynthetic Prokaryotes, Plenum Press, New York.

Roels, J. A., 1983, Energetics and kinetics in biotechnology, Elsevier, New York.

Sánchez, J. F., Fernández-Sevilla, J. M., Acién, F. G., Cerón, M. C., Pérez-Parra, J. and Molina Grima, E., 2008, Biomass and lutein productivity of Scenedesmus almeriensis: influence of irradiance, dilution rate and temperature, Biotechnological Products and Process Enginering. Appl Microbiol Biotechnol, Vol. 79, No. 5, pp. 719-729.

Serenotti, F., Crespi, B. A., and Torres, L. G., 2004, Contribuição à modelagem da produção de Spirulina maxima em fotobioreatores, Revista Univ. Rural. Vol. 23, No. 1, pp. 8-17. (in Portuguese)

Soares, D., 2010, Avaliação do crescimento celular e da produtividade de lipídeos de microalgas marinhas em diferentes regimes de cultivo, Master Thesis, Universidade Federal do Paraná, Curitiba, Brazil. (in Portuguese)

Taiz, L. and Zeiger, E. 2006, Fisiologia Vegetal, Ed. Artmed. Porto Alegre, Brazil. (in Portuguese)

Vargas, J. V. C., 2007, Núcleo de pesquisa e desenvolvimento de energia auto-sustentável a partir do biodiesel e outras fontes. Projeto financiado pelo Conselho Nacional de Desenvolvimento Científico e Tecnológico do Edital 039/2007, UFPR. (in Portuguese)

Xu, H., Miao, X., and Wu, Q., 2006, High quality biodiesel production from a microalgae Chlorella protothecoides by heterotrophic growth in fermenters. Journal of Biotechnology, Vol. 126, No. 4, pp. 499-507.

Received: September 09, 2008

Revised: October 09, 2008

Accepted: November 09, 2008 